\title{
Little Ice Age advance and retreat of Glaciar Jorge Montt, Chilean Patagonia
}

\author{
A. Rivera ${ }^{1,2}$, M. Koppes ${ }^{3}$, C. Bravo ${ }^{1}$, and J. C. Aravena ${ }^{4}$ \\ ${ }^{1}$ Centro de Estudios Científicos (CECS), Valdivia, Chile \\ ${ }^{2}$ Departamento de Geografía, Universidad de Chile, Santiago, Chile \\ ${ }^{3}$ Department of Geography, University of British Columbia, Vancouver, Canada \\ ${ }^{4}$ Centro de Estudios del Cuaternario Fuego-Patagonia y Antártica (Fundación CEQUA) Conicyt Regional R07C1002., \\ Punta Arenas, Chile
}

Correspondence to: A. Rivera (arivera@cecs.cl)

Received: 2 September 2011 - Published in Clim. Past Discuss.: 5 October 2011

Revised: 30 December 2011 - Accepted: 19 January 2012 - Published: 5 March 2012

\begin{abstract}
Glaciar Jorge Montt $\left(48^{\circ} 20^{\prime} \mathrm{S} / 73^{\circ} 30^{\prime} \mathrm{W}\right)$, one of the main tidewater glaciers of the Southern Patagonian Icefield (SPI), has experienced the greatest terminal retreat observed in Patagonia during the past century, with a recession of $19.5 \mathrm{~km}$ between 1898 and 2011. This retreat has revealed trees laying subglacially until 2003 . These trees were dated using radiocarbon, yielding burial ages between 460 and $250 \mathrm{cal}$ yrs BP. The presence of old growth forest during those dates indicates that Glaciar Jorge Montt was upvalley of its present position before the commonly recognized Little Ice Age (LIA) period in Patagonia. The post-LIA retreat was most likely triggered by climatically induced changes during the 20th century; however, Glaciar Jorge Montt has responded more dramatically than its neighbours. The retreat of Jorge Montt opened a $19.5 \mathrm{~km}$ long fjord since 1898 , which reaches depths in excess of $390 \mathrm{~m}$. The bathymetry is well correlated with glacier retreat rates, suggesting that dynamic responses of the glacier are at least partially connected to near buoyancy conditions at the ice front, resulting in high calving fluxes, accelerating thinning rates and rapid ice velocities.
\end{abstract}

\section{Introduction}

The Patagonian Icefields (Fig. 1) are the largest temperate ice masses in the Southern Hemisphere. The two main ice bodies, the Northern and the Southern Icefields (NPI and SPI, respectively), have 118 glaciers covering approximately $17000 \mathrm{~km}^{2}$ (Rivera et al., 2007; Aniya et al., 1996). Most of these glaciers have been retreating since a maximum glacier extent between the 16th and 19th centuries (Masiokas et al., 2009; Glasser et al., 2011), followed by widespread glacier shrinkage during the 20th century. This period of maximum glacier extend is in synchronicity with the Little Ice Age (LIA), defined as the period of enhanced glacial conditions in Europe between the 16th and 19th centuries periods (Matthews and Briffa, 2005). Despite a general retreating trend since the end of the LIA (Rignot et al., 2003; López et al., 2010), some glaciers, especially Glaciar Moreno, Pío XI and Trinidad in the SPI, have demonstrated anomalous advances during the 20th century (Rivera et al., 1997a, b; Masiokas et al., 2009). Others have suffered rapid retreats into deep lakes and fjords, including Glaciar O'Higgins (Casassa et al., 1997) and Glaciar Upsala (Skvarca et al., 2002). These anomalously rapid retreats have been related to (1) calving of the ice fronts, (2) ice flow acceleration in the lower reaches of the glaciers, and (3) surface elevation changes as the glaciers thin. All three factors are ultimately triggered by regional warming. However, the specific behaviour of each ice body will depend on the bathymetry of the lakes or fjords into which the glaciers are calving, which will in turn influence the volume of ice lost to calving and which may be a cause, or a consequence of, any acceleration in ice flow (Benn et al., 2007).

The western (Chilean) side of Patagonia, where many of the glaciers that calve into seawater are located, is an archipelago with thousands of islands and channels. The region has been visited since the 16th century as numerous explorers crossed the Strait of Magellan (Martinic, 1999). One of the first visitors to leave an account of a perilous trip was Juan Ladrillero, who navigated western Patagonia in 

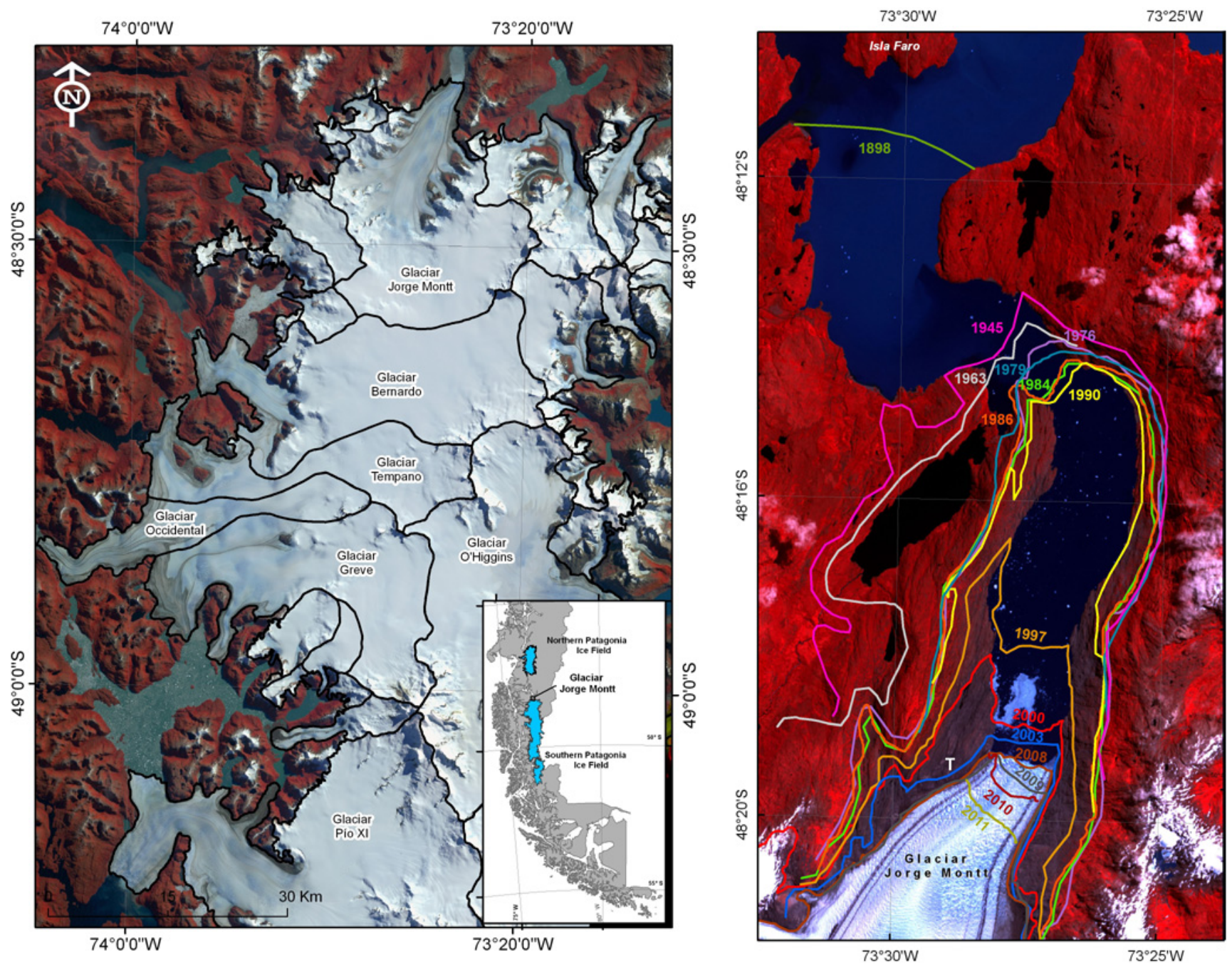

Fig. 1. Left: the main glacier basins of the northern part of the SPI. The background satellite image was acquired on 2 April 2003. Right: frontal positions of Glaciar Jorge Montt, 1898-2011. The location of the dendrochronology sampling site is indicated to the west of the 2010 terminus (Letter T). The background ASTER image was acquired on 4 February 2008.

1597/98. During his explorations, navigation was made challenging by the many icebergs coming from Glaciar Pío XI, at the end of Fiordo Eyre (Bertrand, 1880). This and other narratives of icebergs in historical accounts have been used to define a cold period during the second half of the 16th century (Prieto and Herrera, 1998), coincident with the beginning of the LIA, which reached its maximum extent around AD 1650 (Villalba, 1994; Villalba et al., 2003).

The first effort to map glaciers in Patagonia was conducted by King (1839), using data collected during the British Hydrographic expeditions of 1826-1830 on board HMS Beagle, Adventure and Adelaide (which included Charles Darwin). Between January and April 1830, the HMS Adelaide, under Lieutenant Skyring, mapped Fiordo Eyre, including the ice front position of Glaciar Pío XI. Comparing his map to the present (2011) position of the glacier front, Pío XI has advanced almost $12 \mathrm{~km}$.
These accounts of Pío XI are rare and relatively little is known about the long term historical variations of other glaciers in the SPI, such as Glaciar Jorge Montt $\left(48.2^{\circ} \mathrm{S} / 73.5^{\circ} \mathrm{W}, 500 \mathrm{~km}^{2}\right.$ in 2011$)$. Jorge Montt is one of the largest tidewater calving glaciers of the SPI, flowing north from one of the central plateaus of the SPI (shared with Glaciares Occidental, Témpano and Bernardo, among others) (Fig. 1). The glacier calves into an unnamed fjord that opened after glacier retreat since 1898, when the first map including the glacier was published by Risopatrón (1905). At this time, the ice front extended to within $3 \mathrm{~km}$ of Fiordo Calen, also known as Canal Baker (Fig. 1). The lower tongue has been thinning dramatically in recent decades, with an areal thinning rate (total volume loss divided by the area per year) of $3.3 \mathrm{~m} \mathrm{yr}^{-1}$ between 1975 and 2000, the fastest thinning observed in Patagonia (Rignot et al., 2003). 
In this paper we present the 20th century changes from Glaciar Jorge Montt based on historical records, aerial photographs and satellite imagery. The main purpose of this paper is to understand calving glacier behaviour during and since the LIA, considering local topographic conditions and their possible influence on glacier dynamic responses. We present all available historical records, aerial photographs and satellite imagery of the glacier, which we use to analyse in detail changes in ice front position over the last 200300 years, and compare these changes to a recent survey of the bathymetry of the opening fjord as well as to dendrochronological dates collected near the 2010 terminus. We then compare these historical variations to changes documented at other glaciers within the northern portion of the SPI, in order to highlight the key variables that drive differences in glacier response to regional climate change.

\section{Data and methods}

\subsection{Historical accounts}

The first historical account of Glaciar Jorge Montt was recorded at the end of the 16th century (Martinic, 1999). This record includes no map, and the description is very difficult to map and interpret. Several historical accounts from the 19th century were made by the Chilean Boundary Commission that travelled through southern Chile mapping the region while looking for the continental watershed divide, among other features. These accounts have sufficient detail to fix glacier positions and characterize some of the lower ice tongues.

\subsection{Aerial photographs}

The earliest aerial photos collected in Patagonia were acquired in 1944/45 by the United States Air Force, which surveyed the whole of Southern Chile. The TRIMETROGON flight was composed of one vertical and two oblique lines of photographs and was used to prepare a 1:250 000 preliminary cartography of Patagonia, including the position of almost every glacier in the Patagonian icefields. This imagery did not include the surface topography of the ice, which was only a preliminarily estimate. Subsequent aerial photo surveys only collected vertical images, including the McHurd photo series taken in 1975, at approximately 1:50000 scale.

The aerial photos collected in Patagonia are available solely as paper copies, and many of the series have no overlapping areas for photogrammetric analysis. The photos were analysed with stereoscopes, and then scanned and adjusted to modern cartography using GIS software, enabling us to georeference the scanned photos to the most recent cartography. The errors inherent in using this procedure to adjust the photos to satellite images or cartography are considerable when applied to the whole photo (i.e. distortion increases away from the central point); however, the accuracy improves significantly when focusing on particular areas within the centre of the images.

\subsection{Satellite images}

The oldest available satellite images of the region were collected by the Corona spy satellite in 1963, and by the Keyhole sensor in 1979. In August 1963, the first Corona satellite image of the Patagonian icefields was collected in what is now known as "the declassified mission" (Table 1). Given the midwinter acquisition date of the imagery, most of the icefields were covered in snow; however, the frontal positions of many of the SPI glaciers are clearly visible, allowing the termini to be mapped accurately. These images are also only available as paper copies, and were analysed using the same procedure as for the aerial photographs.

In 1976, the first Landsat MSS successfully collected images from the region, and these were made digitally available (Table 1). In 1979, two images were available, one from March and second from August, which show no significant change in glacier position between 1976 and 1979.

The digital satellite images were geo-referenced to regular cartography, and orthorectified using the Space Shuttle Radar Topography mission (SRTM) data set. A manual adjustment was applied to ensure a more precise overlap between the images, using tie points selected from the most clearly visible features around the study area. Considering the resolution of the images and the geo-referencing process, a systematic horizontal error in the order of one or two pixels is assumed, according to the method described in Williams et al. (1997) and Rivera et al. (2007).

The full dataset of satellite images was projected into a Universal Transversal Mercator format (UTM-zones 18S and 19S) under the WGS84 datum. Database management and analysis were carried out using GIS tools from ENVI 4.5 and ArcMap.

Several false-colour composite images derived from the visible and/or near infrared bands were obtained by layer stacking procedures (Paul et al., 2002), including Landsat $5 / 4 / 3$, Landsat $5 / 4 / 1$ and ASTER $3 / 2 / 1$; this produced the best discrimination between the glaciers and nonglaciated surfaces (vegetation, water bodies and seasonal snow patches). Glacier outlines were manually digitised from each image. Ice divides were obtained by overlapping SRTM layers on satellite composite images, and then deriving contour lines from the SRTM DEM, allowing us to define the main glacier flow lines.

A full coverage mosaic of the SPI was acquired in October 2000 with a Landsat ETM+ image (Table 1). This mosaic allowed mapping the basin outlines of the glaciers analysed. These outlines are similar to the polygons drawn by Aniya et al. (1996), with minor modifications due to the addition of the SRTM data. 
Table 1. Data used to calculate frontal variations of Jorge Montt Glacier, 1898-2011.

\begin{tabular}{|c|c|c|}
\hline $\begin{array}{l}\text { Date } \\
\text { (month/day/age) }\end{array}$ & Sensor & $\begin{array}{l}\text { Spatial resolution } \\
(\mathrm{m})\end{array}$ \\
\hline $12 / 18 / 1898$ & Historical record (Steffen, 1898) & Not applicable \\
\hline Summer 1944/1945 & TRIMETROGON aerial photographs & Oblique \\
\hline $08 / 26 / 1963$ & Declassified Corona satellite image & Not available \\
\hline Summer 1974/1975 & Mc Hurd aerial photographs & Not available \\
\hline $02 / 25 / 1976$ & Landsat MSS & 79 \\
\hline 03/08/1979 & Landsat MSS & 79 \\
\hline 03/20/1979 & Keyhole KH-9 & Not available \\
\hline $12 / 26 / 1984$ & Landsat TM & 30 \\
\hline $10 / 04 / 1986$ & Landsat TM & 30 \\
\hline Summer 1990 & Landsat TM & 30 \\
\hline 02/04/1997 & Landsat TM & 30 \\
\hline $10 / 27 / 2000$ & Landsat ETM+ & 30 \\
\hline $04 / 02 / 2003$ & Landsat ETM+ & 30 \\
\hline $02 / 04 / 2008$ & ASTER & 15 \\
\hline 06/05/2009 & ASTER & 15 \\
\hline $02 / 25 / 2010$ & ASTER & 15 \\
\hline $01 / 15 / 2011$ & Terrestrial photography & Not applicable \\
\hline
\end{tabular}

Unfortunately, the only satellite image available for the 1990s was obtained in 1997. Cloud cover in this image is considerable; however, the ice front is distinguishable between the mist and the brash ice covering most of the newly vacated fjord.

Two ASTER scenes were acquired on 16 and 25 February 2010 (Table 1), at the end of the austral summer, and used to estimate the most recent Equilibrium Line Altitudes (ELA) of the major glaciers of the SPI.

\subsection{Topographic data}

The first detailed topography of the area was based upon the McHurd aerial photographs of 1975, prepared by the Military Geographical Institute of Chile (IGM) at 1:50 000 scale. The map includes the ice front position of Glaciar Jorge Montt and the surface topography of the glacier up to approx. $1000 \mathrm{~m}$ a.s.l., where the stereoscopic capabilities of the aerial photography was lost due to white surfaces of fresh snow. The spatial resolution of the DEM derived from this map is $50 \mathrm{~m}$ and the vertical accuracy is $19 \mathrm{~m}$ (Rivera et al., 2007).

In 2000, the Patagonian icefields region was included in the SRTM DEM dataset with resolution of $90 \mathrm{~m}$ for Patagonia, and the glaciers are almost completely included in the DEM except for in the upper reaches of the plateaus, within the accumulation areas, where data were scarce. The vertical accuracy of this dataset is better than $16 \mathrm{~m}$ (Bamber and Rivera, 2007). Hypsometric curves of the main glaciers were derived from SRTM data using the glacier basins for the same year (2000).
In December 2002 and 2008, airborne campaigns were conducted from a Chilean Navy Orion P3 airplane using the NASA Airborne Topographic Mapper (ATM) laser to survey the surface topography of Glaciar Jorge Montt. The campaign covered two longitudinal profiles from sea level up to the ice divide, with decimeter accuracy (Krabill et al., 1995).

The ASTER scene acquired in 16 February 2010 was selected for an ASTER DMO (on demand) DEM, with spatial resolution of $30 \mathrm{~m}$ and vertical accuracy of $21 \mathrm{~m}$.

\subsection{Bathymetry}

In February 2010, we conducted a field campaign to map the glacier by boat. Access to the ice front was challenging due to the vast amount of brash ice in the inner fjord, confirming high calving rates of the glacier. In spite of these difficulties, the terminus of the glacier was reached and mapped from a zodiac. We also were able to explore the western margin of the glacier, where two stereographic time-lapse cameras were installed in order to measure surface ice velocities (Rivera et al., 2012). These cameras collected continuous imagery until 22 January 2011.

The depth and subsurface of the new fjord left by the retreating glacier was surveyed with the following instruments/methods: (1) A GARMIN GPS-sonar receiver model GPSMAP 188c, able to locate the position of each bathymetric measurement ( $3 \mathrm{~m}$ accuracy), as well as to penetrate up to $420 \mathrm{~m}$ of sea water. (2) A FURUNO sonar system installed on the yacht provided by a private company Waters of Patagonia, which provided logistical support during the February 2010 campaign to the area. (3) A Datasonics Bubble Pulser sub-bottom profiler, using a $4 \mathrm{~m}$ long hydrophone 
and GeoAcoustic amplifier. This system allowed us to survey deeper waters, as well as map the submarine sediments in the fjord. It was able to penetrate up to $250 \mathrm{~m}$ of soft sediment deposits. The analysis of these sediments is part of a subsequent study.

The data were collected along longitudinal and traverse tracks crossing the fjord spaced approximately $500 \mathrm{~m}$ apart. The data coverage was very dense in some parts of the fjord, whereas other regions were sparsely surveyed due to the presence of ice precluding navigation. The area near the ice front in February 2010 was surveyed along a transverse profile located only $100 \mathrm{~m}$ from the terminal ice cliff. Using all available data points, a linear interpolation method was applied to infer the bathymetry between tracklines, resulting in a bathymetric map of the fjord with $20 \mathrm{~m}$ contour intervals.

\subsection{Dendrochronology}

In February 2010, while surveying the glacier margin, several pieces of semi-buried Nothofagus sp. trees were discovered in a small, tributary valley $750 \mathrm{~m}$ from the 2010 glacier margin in a location that was covered by ice until at least 2000. Samples were collected from the outer rings of two trees for radiocarbon analysis. Samples were sent to the Beta Analytic Radiocarbon Dating Laboratory for ${ }^{14} \mathrm{C}$ dating. The INTCal04 database was used for radiocarbon age calibration, following the approach of Talma and Vogel (1993).

In January 2011, thirteen cross sections were obtained from the same Nothofagus sp. trees discovered close to the glacier margin in February 2010. The sections were analyzed following standard dendrochronological procedures and 26 radii were measured and cross-dated to construct a floating (i.e. without calendar ages) ring-width chronology from the locality.

\section{Results}

\subsection{Historical extent of Glacier Jorge Montt}

The first detailed account of this glacier was written by H. Steffen, a German geographer, hired by the Chilean Boundary Commission to study the geography of Patagonia during the boundary controversy between Chile and Argentina (Pozo, 2005). He visited the area in December 1898 onboard the steamer Condor, mapping the area (Fig. 1). During this trip, he spotted a great glacier (Ventisquero in Spanish), covered by long lateral and medial moraines, descending from the icefield calving into Fiordo Baker (Steffen, 1898). This glacier was later named Jorge Montt in honour of a president of Chile (1891-1896). A few years later Risopatrón (1905), also working for the Chilean Boundary Commission, published a more comprehensive map of the region, confirming that the terminus of Glaciar Jorge Montt was in a similar position to that of the Steffen survey of 1898 .
The USAF TRIMETROGON survey of 1944/45 documented that the terminus of Glaciar Jorge Montt had retreated approximately $6.7 \mathrm{~km}$ since 1898 , a retreat rate of $146 \mathrm{~m} \mathrm{yr}^{-1}$ (Table 2). The photos also confirmed the presence of the morainic bands described by Steffen (1898), but by this time only the lateral moraine on the eastern side of the tongue reached directly into the ocean. The lateral moraine on the western side had a more complex shape consisting of two lateral flows, not reaching the ocean but terminating in a side valley where both flows joined together and were partially calving into a small freshwater lagoon.

The 1963 Corona image of Glacier Jorge Montt showed a moderate frontal retreat of $195 \mathrm{~m}$ since 1945 (Table 2). The lower tongue of the glacier was partially debris covered, especially the western margin which ends in a lateral valley. In 1963, both lateral moraines of Jorge Montt are reaching the ocean, and little ice was visible in the western side valley described in 1945 as partially occupied by ice with a complex surface moraine shape. In the region where the left lateral arm was in 1945 overflowing into the lateral valley, the 1975 image showed that a small tongue has separated from the main ice flow direction, and protrudes $2 \mathrm{~km}$ into this lateral valley, ending in a steep slope without any visible calving activity. The western valley, now ice-free, shows a river coming from the upper slopes, a marshy area and a lake. The whole valley is covered by grass and is free of forest cover, indicating that the ice covering this area had melted away in situ (dead ice) some time since 1963. Between 1963 and 1976, the ice front retreated $530 \mathrm{~m}$ (Table 2).

The glacier in 1976 was calving into the fjord, with both lateral moraines reaching tidewater. No dead ice is visible in the western lateral valley. Between 1976 and 1979 the central part of the glacier in the middle of the fjord retreated $321 \mathrm{~m}$, while the western margin remained relatively stable (Fig. 1).

During the 1980s the glacier front was quite stable, with minor fluctuations and minimum retreat. However, after 1990 the glacier underwent a sudden, dramatic and almost catastrophic retreat. Interestingly, in the 1997 image, the western side of the calving front extends $3 \mathrm{~km}$ north from the main calving front, in a narrow lateral band along the fjord edge. This partially debris-covered ice is a remnant portion of the retreating glacier, hanging onto the margin of the fjord as grounded ice, with little calving activity. This type of "dead ice" is melting in situ and it is almost disconnected from the main trunk of the glacier and therefore not fed by new ice coming from the upper reaches of the icefield.

After 1997 the glacier front stabilized and retreat slowed during the 2000s. The "dead ice" observed in the $1997 \mathrm{im}$ age is gone and the lateral moraines are calving directly into the fjord. However, by 2000, a new area of debris covered "dead ice" was observed extending $1.5 \mathrm{~km}$ north of the 2000 calving front along the western margin of the glacier, with a similar narrow shape compared to that observed in 1997. This region of stagnant ice, almost detached from the main glacier, had disappeared by 2003 , when the entire glacier 
Table 2. Frontal variations and water depths along the centreline of the Jorge Montt new fjord.

\begin{tabular}{cccccc}
\hline Period & $\begin{array}{c}\text { Number } \\
\text { of years } \\
(n)\end{array}$ & $\begin{array}{c}\text { Frontal } \\
\text { retreat } \\
(\mathrm{m})\end{array}$ & $\begin{array}{c}\text { Frontal } \\
\text { change rate } \\
\left(\mathrm{m} \mathrm{yr}^{-1}\right)\end{array}$ & $\begin{array}{c}\text { Mean water } \\
\text { depth } \\
(\mathrm{m})\end{array}$ & $\begin{array}{c}\text { Maximum water } \\
\text { depth } \\
(\mathrm{m})\end{array}$ \\
\hline $1898-1945$ & 46 & 6731 & -146 & -67 & -115 \\
$1945-1963$ & 18 & 195 & -11 & -115 & -140 \\
$1963-1976$ & 13 & 530 & -41 & -140 & -168 \\
$1976-1979$ & 3 & 321 & -107 & -130 & -175 \\
$1979-1984$ & 5 & 562 & -112 & -150 & -221 \\
$1984-1986$ & 2 & 41 & -20 & -220 & -228 \\
$1986-1990$ & 4 & 240 & -60 & -200 & -240 \\
$1990-1997$ & 7 & 6600 & -943 & -220 & -370 \\
$1997-2000$ & 3 & 1828 & -609 & -310 & -342 \\
$2000-2003$ & 3 & 422 & -141 & -210 & -279 \\
$2003-2008$ & 5 & 570 & -114 & -150 & -220 \\
$2008-2009$ & 1.3 & 400 & -308 & -220 & -332 \\
$2009-2010$ & 0.7 & 403 & -576 & -290 & -391 \\
$2010-2011$ & 0.9 & 644 & -716 & Not available & Not available
\end{tabular}

front calved directly into the fjord without lateral extensions along the margins. The disappearance of the stagnant ice exposed several trees that had been buried in-situ and were sampled in 2010 and 2011 (see location of samples in Fig. 1).

The time-lapse imagery collected in 2010-2011 shows a further retreat of the terminus of $\sim 1 \mathrm{~km}$, with a total area lost of about $1.48 \mathrm{~km}^{2}$ during 2010 . The images also captured a massive calving event between 16 and 25 February 2010 with a total area loss of $0.31 \mathrm{~km}^{2}$. Analysing the photos closely, many calving events were observed to produce large icebergs, some with semi tabular shapes. The fjord remained predominantly covered by icebergs and brash ice throughout 2010. However, the front of the glacier also showed evidence of upwelling, as seen in semi-circular, ice-free areas of open sea water next to the ice front. Along both lateral margins of the main tongue, narrow bands of debris-covered ice were hanging from the mountain flanks. These "dead ice" areas were almost disconnected from the main glacier flow and melting in situ.

In synthesis, the glacier retreated between 1898 and 2011 (January) a total of $19.5 \mathrm{~km}$.

\subsection{Bathymetric survey}

The bathymetry at the 1898 ice front position (Fig. 2) indicates this stable ice front position overlies a submarine moraine arc crossing the fjord with minimum water depths of $16 \mathrm{~m}$ and a narrow channel of $\sim 45 \mathrm{~m}$ depth along the western edge of the outer fjord.

The submerged section of the outer fjord between the 1898 and 1945 terminal positions (Fig. 2) is typically "U" shaped with a flat bottom of maximum depth $115 \mathrm{~m}$. The 1945 terminus coincides with another subaquatic ridge under less than $80 \mathrm{~m}$ water depth.
The bathymetry between the 1945 and 1990 terminal positions shows a gently sloping valley floor with increasing water depth. Between the 1990 and 1997 ice front positions, the fjord bottom drops steeply to reach a maximum depth of $370 \mathrm{~m}$ (Fig. 2). The position of this deep part of the fjord coincides with the timing of the most rapid retreat during the 1990s. It also coincides with the period when the glacier underwent the strongest thinning.

Further upfjord of the 1997 terminus position, water depths decrease to a mean of $-210 \mathrm{~m}$ close to the 20002003 ice front, before dropping again to a maximum depth of $-391 \mathrm{~m}$ at the 2010 ice front (Fig. 3).

\subsection{Thinning rates}

The surface topography of the glacier during the latter half of the 20th century changed dramatically. Rignot et al. (2003) compared the 1975 topography to the SRTM topography (2000), and showed a maximum thinning rate of $18 \mathrm{~m} \mathrm{yr}^{-1}$ between 1975 and 2000 .

Between 2000 and 2002 (Fig. 3), comparing the LIDAR profiles measured during the airborne P3 campaign, the glacier thinned at a mean rate of $31 \mathrm{~m} \mathrm{yr}^{-1}$, the maximum rate of thinning recorded for this glacier. LIDAR profiles in 2002 and 2008 showed a mean thinning rate of $2.8 \mathrm{~m} \mathrm{yr}^{-1}$, which increased to $22 \mathrm{~m} \mathrm{yr}^{-1}$ between 2008 and 2010 .

\subsection{Ice velocities}

The first measurements of ice velocity at Jorge Montt were collected by Enomoto and Abe (1983), who measured surface velocities of $240 \mathrm{~m} \mathrm{yr}^{-1}$ at a grounded lateral tongue of the glacier. Using speckle tracking from RADARSAT-1 images collected in 2004, E. Rignot (personal communication) 
Table 3. Sample dates.

\begin{tabular}{lccl}
\hline Sample ID & $\begin{array}{c}\text { Radiocarbon Age } \\
\text { (AD Cal year) }\end{array}$ & $\begin{array}{c}\text { Two Sigma } \\
\text { Calibrated Age } \\
\text { (years BP) }\end{array}$ & Reference \\
\hline Beta 279215 (CECS 1) & $460 \pm 40$ & $1410-1470$ & This work \\
Beta 279216 (CECS 2) & $250 \pm 40$ & $1520-1580$ & This work \\
& & $1630-1680$ & \\
& & $1770-1800$ & \\
I-3824 & $270 \pm 90$ & $1430-1950$ & \\
\hline
\end{tabular}

obtained values of up to $3460 \mathrm{~m} \mathrm{yr}^{-1}$, at a location $3 \mathrm{~km} \mathrm{up-}$ stream the glacier front. More recently, based upon feature tracking of geo-referenced photos from the fixed cameras installed in 2010, Rivera et al. (2012) obtained a mean value of $4885 \mathrm{~m} \mathrm{yr}^{-1}$ for a complete transverse cross-section at the glacier front, indicating significant acceleration of ice flow in the past three decades.

\subsection{Tree samples}

The first sample (Fig. 4), collected from the outermost perimeter of a tree located along the margin of a proglacial stream $750 \mathrm{~m}$ from the 2010 glacier margin, was dated to $460 \pm 40{ }^{14} \mathrm{C}$ yr BP, with a calibrated age of $1440 \mathrm{cal} \mathrm{AD}$ (Table 3). The second sample, from a tree collected approximately $50 \mathrm{~m}$ from sample 1 , was dated to $250 \pm 40{ }^{14} \mathrm{C}$ yr BP, with a calibrated age of $1650 \mathrm{cal} A D$. However, ${ }^{14} \mathrm{C}$ dates in the time range less than 500 years present non-linear relationships between ${ }^{14} \mathrm{C}$ years and calendar years, adding uncertainty to the age estimation (Telford et al., 2004).

The almost 200 year difference in age between the samples seem to reflect differences in timing of death of the trees and not differences in burial dates or separate glacial advances, as both samples were collected from the outer part of the trees located at the same subglacial deposit and in close proximity, where both were partly buried in the same thin layer of till. The area was scoured by the glacier and most of the surface was bare rock with lag boulders, hence there is no evidence of multiple glacier advances.

Sixteen out of the 26 measured radii from the thirteen collected trees were successfully cross-dated with a mean correlation of 0.457 . The resulting floating chronology covers 276 years (Fig. 5). Although sampled trunks were not found in situ but were part of subglacially deposited material, the good quality of the crossdating results indicates that these trees were coetaneous.

The tree-ring results suggests the area was covered by an old-growth forest dominated by Nothofagus betuloides ("coigue de Magallanes" - Magellanic southern beech) with individuals of average age close to 150 years, co-existing for almost 300 years (total chronology length). The radiocarbon

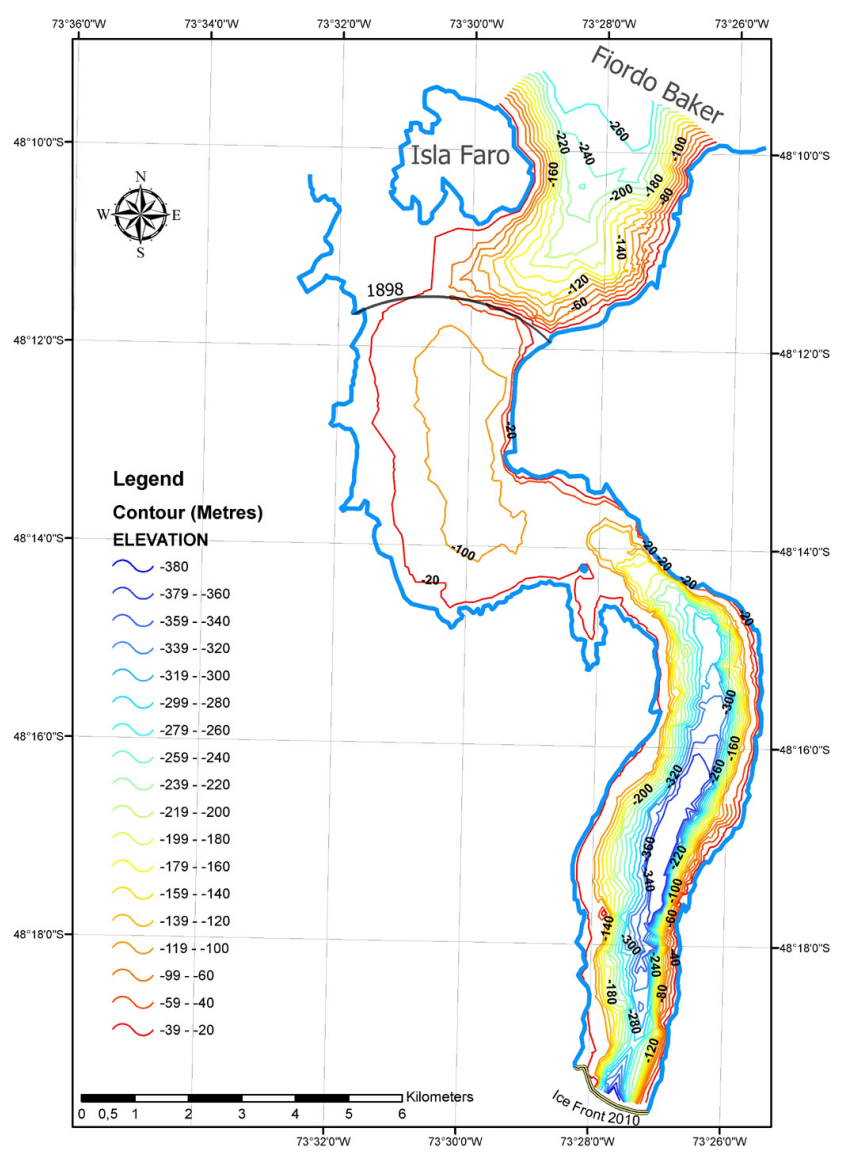

Fig. 2. Bathymetric contour lines from the January 2010 glacier front north to Fiordo Baker (Canal Baker). The glacier front at the end of the Little Ice Age (1898) was located near the junction with Fiordo Baker, $1 \mathrm{~km}$ south of Isla Faro, where the bathymetry shows a shallow transverse ridge approximately $20 \mathrm{~m}$ below sea level.

ages of between 250 and 450 years BP from two of the sampled trees suggests that the tree ring samples were taken from a mature forest that was destroyed by the advance of Glaciar Jorge Montt during the LIA period. If one accepts the $250 \mathrm{BP}$ ${ }^{14} \mathrm{C}$ date, then the glacier advanced after that date, overriding the old growth forest located close to the 2010 glacier front position. 

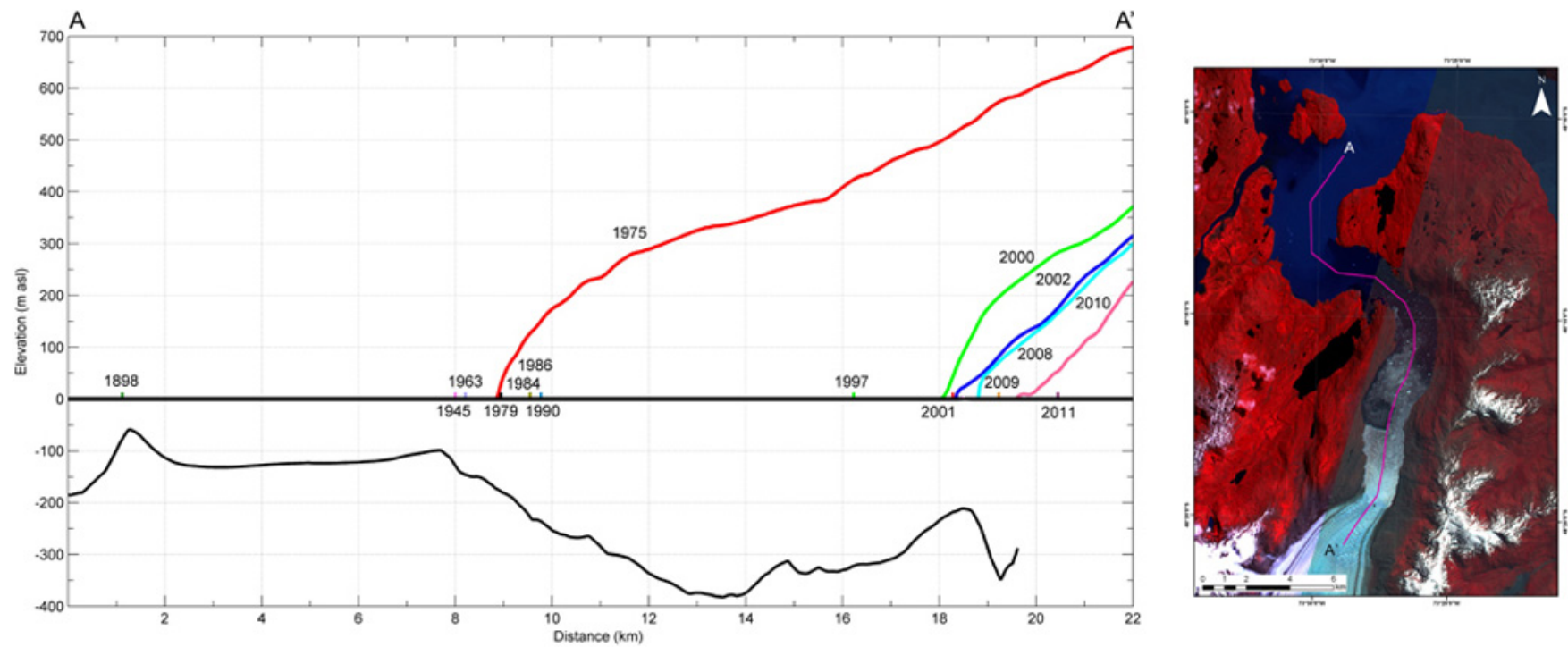

Fig. 3. Longitudinal profile A-A' along the main axis of the fjord, including the frontal positions of the glacier, the glacier surface topography (coloured lines) and the bathymetry (black line). The inset satellite image (February 2010) shows the location of profile A-A'.

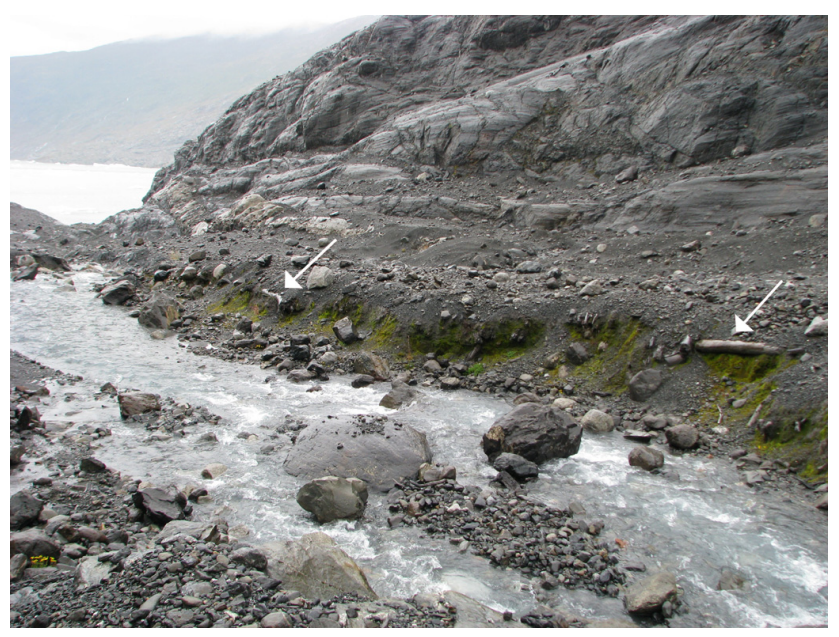

Fig. 4. The buried trees were found near the glacier front in February 2010. In January 2011, cross sections were obtained from these trees (Sample 1 from the tree indicated by the left red arrow, and Sample 2 from the tree pointed by the right red arrow). The left side of the image shows brash ice covering the fjord surface waters near the glacier front.

\section{Discussion and conclusions}

The Glaciar Jorge Montt fastest retreat occurred in the 1990s and again in the past two years when the water depth exceeded $350 \mathrm{~m}$. This also coincides with the timing of the most rapid ice acceleration and thinning, and suggests that calving is increasing with both water depth as well as with higher ice velocities, leading to losses at the ice front in excess of ice flux to the terminus. The change in the glacier

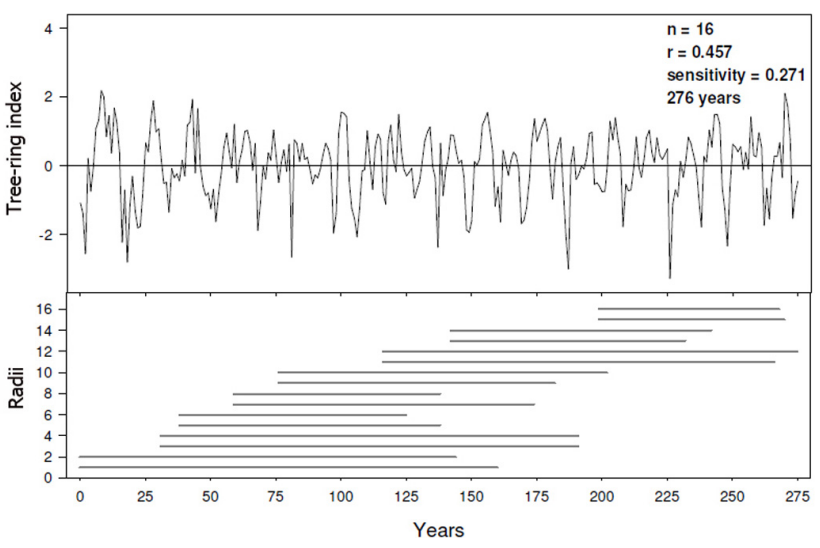

Fig. 5. Tree-ring floating chronology covering 276 years (top graph) developed from 16 radii measured from 13 cross-sections of stumps collected near the 2010 frontal position of Glaciar Jorge Montt. The tree-ring indices show high interannual variability, a mean correlation between samples $(r)$ of ca. 0.5 , and no significant trend. The lower graph indicates the timespan of the samples used to build the floating chronology.

retreat rate is well correlated to the bathymetry (Fig. 6), as postulated by the calving theory (e.g. Meier and Post, 1987; Benn et al., 2007). The relationship, however, is not linear, but suggests a polynomial fit $\left(r^{2}=0.67\right)$ where dynamics are in control of the frontal changes at deeper waters (small water depth changes lead to strong frontal/calving changes), while at shallow waters the frontal changes are less sensitive to water depth changes. The difference between Jorge Montt and several other calving glaciers (Brown et al., 1982) is probably due several factors that need to be analysed in more detail, 
especially the ice velocity distribution, crevassing characteristics, fjord geometry and water pressure within the lower glacier tongue (Van der Veen, 2002).

Jorge Montt is one of the few glacier basins for which regular data of glacier extent are available, allowing for a detailed monitoring of its fluctuations in the last 112 years (December 1898 to January 2011). This record of ice front fluctuations, combined with a bathymetric survey of the glacierabandoned fjord, suggests that water depth is a key factor explaining the variability and magnitude of retreat over the past century. The maximum retreat rates correlate well with deepest waters in the fjord, indicating that the ice was at/or very close to buoyancy conditions throughout much of the past few decades; a condition that can be catastrophic for a temperate calving glacier like Jorge Montt. Near buoyancy conditions were observed in the time-lapse imagery collected from the ice front in 2010, based on the fact that tabular icebergs were observed calving from the terminus, which suggests that large portions of the front were at or near flotation. Rapid calving into deeper water clearly drove catastrophic retreat during the 1990s, and again from 2009 to 2011 when the front reached the deepest part of the fjord (391 m b.s.l.). In contrast, the glacier was stable when its front was grounded on an underwater morainic arc in the outer fjord coincident with the 1898 position of the glacier, and again in 1945 when it grounded on the submarine ridge separating the outer from the inner fjord.

The above description of Glaciar Jorge Montt behaviour is an example of the Tidewater Calving Glacier Cycle (TWG) described by Post et al. (2011), where advances are characterized by moderate ice flow and low calving activity, as observed between 1999 and 2001 at Glaciar Upsala (Skvarca et al., 2003) and the unique advance of Glaciar Pío XI since 1945 (Rivera et al., 1997a, b); stability, characterized by a grounded glacier front due to the development of a submarine terminal moraine (as Glaciar Jorge Montt in 1898 and in 1945-1990); and where rapid catastrophic retreats are a result of coupled rates of ice flow and calving (like Glaciar Jorge Montt between 1990 and the present).

In order to better understand the relationship between the bathymetry and changes in glacier extent, we also investigated the calving flux. As a first approximation, calving flux can be calculated from the fjord cross-sectional bathymetry, the retreat rate and ice velocities, where known (Skvarca et al., 2002). Unfortunately, measured ice velocities are very scarce in Patagonia, and only three measurements are available at Jorge Montt, albeit showing steady acceleration in recent decades.

Using the mean glacier frontal calving velocities based on the depth averaged ice velocity plus the frontal change for each period ( $7.3 \mathrm{~m} \mathrm{~d}^{-1}$ in 2004 and $13.3 \mathrm{~m} \mathrm{~d}^{-1}$ in 2010), the fjord cross-sectional bathymetry (area of $0.26 \mathrm{~km}^{2}$ in 2004 and $0.32 \mathrm{~km}^{2}$ in 2010) calving fluxes were $0.72 \mathrm{~km}^{3} \mathrm{yr}^{-1}$ in 2004 and $2.4 \mathrm{~km}^{3} \mathrm{yr}^{-1}$ in 2010 . These values indicate calving acceleration and are higher than previous estimates ob-

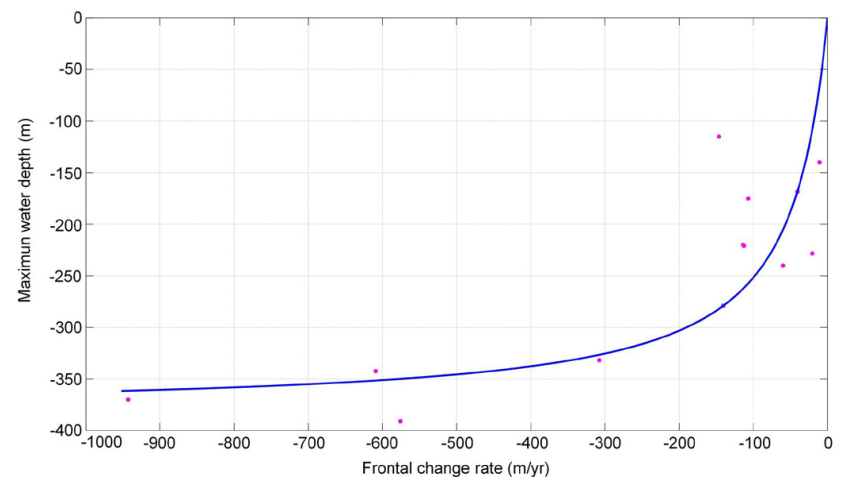

Fig. 6. Relationship between frontal change rates and maximum water depths in Jorge Montt Fjord. The blue line indicates a polynomial best fit regression $\left(r^{2}=0.67\right)$ between frontal change rate and water depth.

tained in Patagonian glaciers (Warren and Aniya, 1999). The question presented by Benn et al. (2007)remains, however, as to whether these calving losses are the cause or the consequence of flow acceleration. The concerted modelling approach needed to answer this question is beyond the scope of this study.

The dates of the radiocarbon samples collected at Jorge Montt are coincident with previous dendrochronologic samples obtained by Mercer (1970) at Bernardo and Témpano glaciers (Fig. 1). Glaciar Bernardo $\left(48^{\circ} 37^{\prime} \mathrm{S}, 73^{\circ} 54^{\prime} \mathrm{W}\right.$, $541 \mathrm{~km}^{2}$ in 2009) currently calves into a lake which formed in 1986 when the terminus retreated $2 \mathrm{~km}$ from an outwash within the LIA moraine, dated by Mercer to $270 \pm 90 \mathrm{yr}$ BP (Mercer, 1970). The terminus was grounded on the outwash plain in 1945, seen in the US Air Force aerial photos. Based on the age of the trees growing on the outermost moraine, Mercer estimated that Glaciar Bernardo reached its maximum extent around AD 1775, only a couple of hundred meters downstream from its 1945 position. Glaciar Témpano $\left(48^{\circ} 43^{\prime} \mathrm{S}, 73^{\circ} 58^{\prime} \mathrm{W}, 292 \mathrm{~km}^{2}\right.$ in 2009$)$ is a glacier with minor tidewater calving activity at the present, because the ice front is partially grounded at a few $\mathrm{m}$ above sea level. In this glacier, Mercer (1970) observed four distinct lateral moraines that formed in the past few centuries, most likely around $\mathrm{AD} 1760$, the maximum advance of the local LIA based on the growth ring pattern on a tilted but living Pilgerodendron uviferum, a conifer tree growing on the outermost moraine. The moraine of the LIA maximum advance at Glaciar Témpano is also very close to its terminal position in 1945; the terminus has since retreated $4.5 \mathrm{~km}$ to its present position. Given these dates, these nearby glaciers experienced a simultaneous advance during the LIA; however, the magnitudes of the LIA advances were significantly different. Glaciar Jorge Montt has retreated $19.5 \mathrm{~km}$ from its 1898 position or its LIA maximum, whereas Bernardo retreated only $2 \mathrm{~km}$ and Témpano only $4.5 \mathrm{~km}$. Differences 


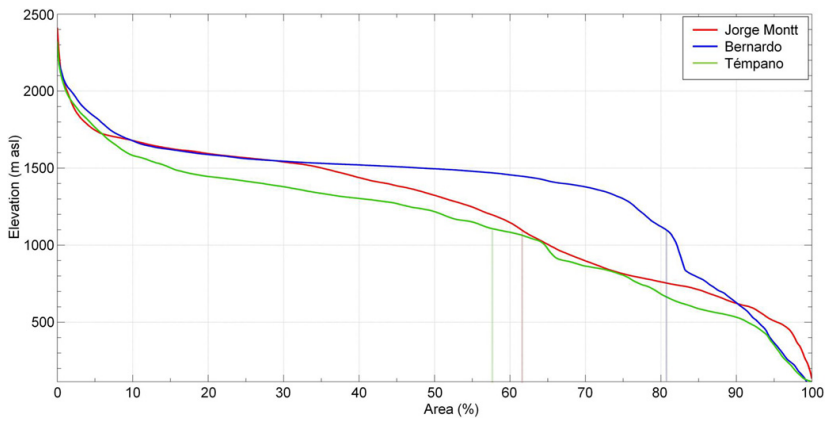

Fig. 7. Hypsometric curves of Glaciares Jorge Montt, Bernardo and Témpano, derived from 2000 AD SRTM digital elevation model. Modern Equilibrium Line Altitude (ELA) for all three glaciers was estimated at $1100 \mathrm{~m}$ a.s.l. The dashed vertical lines show the accumulation area ratio (AAR, a ratio between the accumulation area and the total area of a glacier) position for each glacier. AAR for Bernardo is 0.80, much higher than Jorge Montt (0.61) and Témpano (0.58). The present ELA at Jorge Montt is approaching the main plateau, whilst at Témpano it intersects the main plateau. At Bernardo, the present ELA is still within the steeper lower part of the glacier.

in calving characteristics could explain these differences in terminus behaviour, as the Bernardo front is grounded and Glaciar Témpano is a tidewater calving glacier with very minor activity when compared to Jorge Montt. In this sense, the bathymetry is more likely the main difference between these glaciers.

Radiocarbon dating of samples collected near the present glacier front indicates that the glacier front was at its current 2011 position prior the Little Ice Age. A proglacial forest was overridden by a LIA advance and remained buried and preserved until 2003 when the ice covering the dead trees retreated. During the LIA the glacier advanced to most likely stabilize at the 1898 position, as the terminus location in 1898 is coincident with a well preserved submerged arcuate moraine, typically generated when the ice advances, removes and reworks subglacial deposits to accumulate in an arcuate form at the maximum (e.g. LIA maximum) position.

Another difference between these glaciers is their hypsometries (Fig. 7) or area-altitude distributions (Rivera et al., 2011). The hypsometries of Glaciares Jorge Montt and Témpano are very similar, with a large accumulation area situated on a broad plateau surrounded by peaks and a narrow tongue gently flowing down an outlet valley. In contrast, Bernardo has a much steeper accumulation area and a smaller ablation area. Based upon the February 2010 ASTER image, the ELA for all three glaciers was estimated to be approximately $1100 \mathrm{~m}$ a.s.l.; the resulting accumulation area ratios (AAR) approach 0.62 for Jorge Montt, 0.58 for Témpano and 0.81 for Bernardo.
With a gentle slope at the elevation of the ELA, the mass balance of Jorge Montt is much more sensitive to shifts in the ELA, especially when the ELA intersects the broad accumulation plateau. For a similar rise in ELA, the steeper topography of Bernardo would result in a smaller change in mass balance, i.e. the glacier is less sensitive to climatic change. This condition, and the smaller AAR, partially explains why Jorge Montt and Témpano have retreated more dramatically than Bernardo in the past few decades. Given continued warming in the region, however, a further rise in the ELA at Bernardo may cause the ELA to intersect its flatter upper accumulation area, possibly triggering an accelerated reduction of its AAR and resulting in frontal retreat rates more similar to that seen at its neighbours.

Another interesting characteristic of Glaciar Jorge Montt is the presence of dead or stagnant ice along the margins of the retreating tongue. The subaerial topography adjacent to the main glacier tongue is flat enough to anchor some of the ice from the main flow of the glacier. For example, in 1945, the lower part of the glacier flowed over a low ridge on the western flank of the glacier and occupied a lateral valley, where the ice melted in situ, with only a small portion of the ice front calving into a proglacial lagoon. The same conditions were observed in 1963, 1997, 2000 and most recently in the time-lapse photos collected between 2010 and 2011. The importance of this "dead ice" is that it can lead to preservation of subglacial and organic material overridden by the ice, such as the buried trees found in 2010. As the ice along these margins is flowing much more slowly than the main glacier tongue, subglacial deposition and minimal abrasion can preserve the pre-glacial landscape. These locations are therefore promising sites for more detailed investigations of material overridden by glacial advance during the LIA, which could be well preserved. The stagnant ice also confirms the importance of calving in driving retreat of the ice front, since the ice that grounded above sea level remained in place for years after the main calving tongue had retreated.

The water depth at the 2010 glacier position has a maximum depth of $391 \mathrm{~m}$, implying a near buoyancy condition for the frontal portion of the ice tongue. The height above buoyancy, or ice thickness in excess of flotation $(F)$, is defined as

$F=(h+w)-w s \rho / i \rho$

where $w$ is the water depth near the 2010 ice front, $h$ is the mean ice height above water level near the front, $i \rho$ is the ice density $\left(900 \mathrm{~kg} \mathrm{~m}^{-3}\right)$, and $s \rho$ is the density of sea water $\left(1024 \mathrm{~kg} \mathrm{~m}^{-3}\right)$. Given $w=391 \mathrm{~m}$ and $h=75 \mathrm{~m}$ in 2010 , $F$ yields $21 \mathrm{~m}$, a value very close to the ice cliff height of the glacier. Analysing the sequence of time-lapse images obtained with the fixed cameras, the ice front terminates in a clear, prominent tall cliff with heights that fluctuated between 0 and $45 \mathrm{~m}$ a.s.l. in 2010, with a mean of $22 \mathrm{~m}$ a.s.l. In many of the images, a large number of icebergs can be seen calving off the front, several of which were tabular in shape. 
During the days in which tabular icebergs were generated, the height of the ice cliff is less than $20 \mathrm{~m}$, hence the ice was near floating conditions.

The significant differences in response to climate changes during the Little Ice Age for nearby and relatively similar glaciers in Patagonia highlight the importance of glacier shapes, ice front dynamics related to calving activity and the inner fjords characteristics, all factors controlling ice mass responses to regional changes in climate and in the ocean.

\section{Supplementary material related to this article is available online at: http://www.clim-past.net/8/403/2012/ cp-8-403-2012-supplement.pdf.}

Acknowledgements. This research was funded by Fondecyt 1080320. We thank JC and Allen Szydlowski (Waters of Patagonia) for providing fantastic logistical support in the field. Bernard Hallet, Chuck Nittrouer, Katie Boldt and Adam Barker from University of Washington, USA, Dick Sylwester, Golder Associates Inc., Daniela Carrión, Camilo Rada and Sebastián Cisternas from CECS, Claudia Mansilla and Carla Henríquez from CEQUA, collaborated with this research. The University of Washington participation was rendered possible by funding from the Quaternary Research Center. Satellite images were provided by GLIMS. Andrés Rivera also thanks the Guggenheim Foundation. Thanks to Eric Rignot who provided ice velocity data. NASA-Wallops provided ATM data. The Chilean Navy provided the Orion P3 for surveying the glaciers in 2002 and 2008. The Centro de Estudios Científicos (CECS) is funded by the Chilean Government through the Millennium Science Initiative and the Centers of Excellence Base Financing Program of Conicyt.

Edited by: M. H. Masiokas

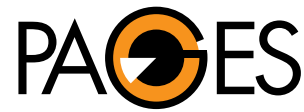

The publication of this article was sponsored by PAGES.

\section{References}

Aniya, M., Sato, H., Naruse, R., Skvarca, P., and Casassa, G.: The use of satellite and airborne imagery to inventory outlet glaciers of the Southern Patagonia Icefield, South America, Photogramm. Eng. Rem. S., 62, 1361-1369, 1996.

Bamber, J. and Rivera, A.: A review of remote sensing methods for glacier mass balance determination, Global Planet. Change, 59, 138-148, 2007.

Benn, D., Warren, C., and Mottram, R.: Calving processes and the dynamics of calving glaciers, Earth Sci. Rev., 82, 143-179, 2007.

Bertrand, A.: Espedición de Juan Ladrillero (1557 a 1559), Anuario hidrográfico de la Marina de Chile, 6, 453-525, 1880.

Brown, C. S., Meier, M. F., and Post, A.: Calving speed of Alaska tidewater glaciers with applications to the Columbia Glacier, Alaska, US Geological Survey Professional Paper, 1258-C, 13 pp., 1982.
Casassa, G., Brecher, H., Rivera, A., and Aniya, M.: A Centurylong Record of Glaciar O'Higgins, Chilean, Patagonia, Ann. Glaciol., 24, 106-110, 1997.

Enomoto, H. and Abe, Y.: Reconnaissance Studies of meteorology and glaciology in Steffen and Jorge Montt Glaciers Patagonia, in: Glaciological and Meteorological Studies in Patagonia Chile by Japanese Research Expeditions in 1967-1982, edited by: Naruse, R., Data centre for glacier research, Japanese Society of Snow and Ice, 11-14, 1983.

Glasser, N. F., Harrison, S., Jansson, K. N., Anderson, K., and Cowley, A.: Global sea-level contribution from the Patagonian Icefields since the Little Ice Age maximum, Nature Geosci., 4, 203-207, 2011.

King, P.: Narrative of the surveying voyages of His Majesty's Ships Adventure and Beagle between the years 1826 and 1836, describing their examination of the southern shores of South America, and the Beagle's circumnavigation of the globe, Proceedings of the first expedition, 1826-30, under the command of Captain P. Parker King, R. N., F. R. S. London: Henry Colburn, 1839.

Krabill, W., Thomas, R., Jezek, K., Kuivinen, K., and Manizade, S.: Greenland ice-sheet thickness changes measured by laser altimetry, Geophys. Res. Lett., 22, 2341-2344, 1995.

López, P., Chevallier, P., Favier, V., Pouyaud, B., Ordenes, F., and Oerlemans, J.: A regional view of fluctuations in glacier length in southern South America, Global Planet. Change, 71, 85-108, 2010.

Martinic, M.: Cartografía Magallánica 1523-1945, Ediciones Universidad de Magallanes, 345 pp., 1999.

Masiokas, M., Rivera, A., Espizúa, L., Villalba, R., Delgado, S., and Aravena, J. C.: Glacier fluctuations in extratropical South America during the past 1000 years, Palaeogeography, Palaeoclimatology, Palaeoecology, 281, 242-268, 2009.

Matthews, J. A. and Briffa, K. R.: The 'Little Ice Age': Reevaluation of an evolving concept, Geografiska Annaler, 87 A, 17-36, 2005.

Meier, M. and Post, A.: Fast Tidewater Glaciers, J. Geophys. Res., 92 B9, 9051-9058, 1987.

Mercer, J. H.: Variations of some Patagonian glaciers since the Late-Glacial: II, Am. J. Sci., 269, 1-25, 1970.

Paul, F., Kääb, A., Maisch, M., Kellenberger, T., and Haeberli, W.: The new remote sensing derived Swiss glacier inventory I: Methods, Ann. Glaciol., 34, 355-362, 2002.

Post, A., O'Neel, S., Motyka, R., and Streveler, G.: A complex relationship between calving glaciers and climate, EOS, 92, 305306, 2011.

Pozo, J.: Hans Steffen: Maestro, Geógrafo y Pionero de la Patagonia, Occidental Revista Universum, 20, 112-123, 2005.

Prieto, M. and Herrera, R.: Naos, clima y glaciares en el Estrecho de Magallanes durante el siglo XVI, Anuario de Estudios Americanos, 55, 413-439, 1998.

Rignot, E., Rivera, A., and Casassa, G.: Contribution of the Patagonia icefields of South America to global sea level rise. Science, 302, 434-437, 2003.

Risopatrón, L.: La Cordillera de los Andes entre las latitudes $46^{\circ} \mathrm{i}$ $50^{\circ} \mathrm{S}$, Imprenta Cervantes 233 pp., 1905.

Rivera, A., Aravena, J. C., and Casassa, G.: Recent Fluctuations of Glaciar Pío XI, Patagonia: Discussion of a Glacial Surge Hypothesis, Mountain Research and Development, 17, 309-322, 1997a. 
Rivera, A., Lange, H., Aravena, J. C., and Casassa, G.: The 20th Century Advance of Glaciar Pío XI, Southern Patagonia Icefield, Ann. Glaciol., 24, 66-71, 1997b.

Rivera, A., Benham, T., Casassa, G., Bamber, J., and Dowdeswell, J.: Ice elevation and areal changes of glaciers from the Northern Patagonia Icefield, Chile, Global Planet. Change, 59, 126-137, 2007.

Rivera, A., Cawkwell, F., Rada, C., and Bravo, C.: Hypsometry, in: Encyclopedia of Snow Ice and Glaciers, edited by: Singh, V., Singh, P., and Haritashya, U., Springer, The Netherlands, pp. 551-554, 2011.

Rivera, A., Corripio, J., Bravo, C., and Cisternas, S.: Glaciar Jorge Montt dynamics derived from photos obtained by fixed cameras and satellite image feature tracking, Ann. Glaciol., 53, 60A152, 2012.

Skvarca, P., De Angelis, H., Naruse, R., Warren, C., and Aniya, M.: Calving rates in fresh water: new data from southern Patagonia, Ann. Glaciol., 34, 379-384, 2002.

Skvarca, P., Raup, B., and De Angelis, H.: Recent behaviour of Glaciar Upsala, a fast-flowing calving glacier in Lago Argentino, southern Patagonia, Ann. Glaciol., 36, 184-188, 2003.

Steffen, H.: Informe preliminar sobre los trabajos de la Comisión exploradora del Canal i Rio Baker, ejecutados en la zona del litoral patagónico, comprendida entre los $46^{\circ}$ y $48^{\circ}$ de latitud sur (diciembre de 1898), in: La Cordillera de los Andes entre las latitudes $46^{\circ}$ i $50^{\circ} \mathrm{S}$, edited by: Risopatrón, L., 1905, Imprenta Cervantes, Santiago, pp. 113-145, 1898.
Talma, A. and Vogel, J.: A Simplified Approach to Calibrating C14 Dates, Radiocarbon, 35, 317-322, 1993.

Telford, R. J., Heegaard, E., and Birks, H. J. B.: The intercept is a poor estimate of a calibrated radiocarbon age, The Holocene, 14, 296-298, 2004.

Van der Veen, C.: Calving glaciers, Progress in Physical Geography, 26, 96-122, 2002.

Villalba, R.: Tree-Rings and glacial evidence for the Medieval Warm Epoch and the Little Ice Age in Southern South America, Climatic Change, 26, 183-197, 1994.

Villalba, R., Lara, A., Boninsegna, J. A., Masiokas, M., Delgado, S., Aravena, J. C., Roig, F. A., Schmelter, A., Wolodarsky, A., and Ripalta, A.: Large-scale temperature changes across the southern Andes: 20th-century variations in the context of the past 400 years, Climatic Change, 59, 177-232, 2003.

Warren, C. and Aniya, M.: The calving glaciers of southern South America, Global Planet. Change, 22, 59-77, 1999.

Williams, R., Hall, D., Sigurosson, O., and Chien, Y.: Comparison of satellite-derived with ground-based measurements of the fluctuations of the margins of Vatnajökull, Iceland, 1973-92, Ann. Glaciol., 24, 72-80, 1997. 